\title{
SIPHONAPTERA COLLECTED BY MR. F. J. COX IN FRANCE.
}

\section{BY DR. KARL JORDAN.}

(With 4 text-figures.)

\begin{abstract}
$\mathrm{A}^{\mathrm{s}}$ we had hardly any specimens of even the commonest fleas from Western France south of the Loire and from Central France, the authorities of the British Museum of Natural History sent Mr. Cox to that country on a collecting expedition for the purpose of trapping mammals and obtaining their Ectoparasites. Mr. Cox spent about six weeks in France, from the second week in August to the end of September 1930, and was successful in finding a dozen species of fleas, among them two new ones. This number may appear small to the uninitiated. It takes, however, a long time to get even half the number of species actually existing in a country, the less common forms either being local or more common at one time of the year than at another. One of the new species represents a new genus allied to Typhloceras.
\end{abstract}

\section{Pulex irritans L. 1758 .}

Ruffec, Charente, August, a small series, on Homo.

\section{Ceratophyllus fasciatus Bose 1801 .}

Nanteuil, Charente, August, 1 \%, on Rattus norwegicus.-La Bourboule, Puy de Dôme district, 1,200 and 1,700 m., 1 ô, 1 †, on Apodemus sylvaticus.

\section{Ceratophyllus turbidus Roths. 1909.}

A series from Poitiers and Croutelle, August, on Apodemus sylvaticus and Evotomys glareolus.-La Bourboule, Puy de Dôme, 1,200 m., on the same hosts.

\section{Ctenophthalmus agyrtes celticus J. \& R. 1922.}

A series from Ruffec and Condac, and Villefagnan near Ruffec, Charente, August, on Apodemus sylvaticus, Mus musculus and Evotomys glareolus. Also 1 f from La Bourboule, Puy de Dôme, September, on Evotomys spec.

It would be of great interest to know how far south, west and east this subspecies actually occurs. Its known range is very wide, extending to the Shetlands and including Ireland. We have a series of both sexes from Brittany; but whether it is this subspecies that occurs in Normandy, or the Central European one, we do not know. The individual variability does not seem to be so great as in England; but this observation may be due to the number of French specimens compared being so much smaller than the number of British ones.

5. Ctenophthalmus arvernus spec. nov. (text-fig. 1).

Closely related to $C t$. agyrtes celticus, but very distinct in the tail-end of the $\hat{\sigma}$. Chaetotaxy almost the same as in Ct. agyrtes.

o. The dense striation on the inner surface of VIII. st. less distinct than in 
Ct. agyrles celticus. Ventral margin of clasper much more evenly convex; manubrium (M) shorter, apically more strongly curved upwards ; upper process $\mathrm{P}^{1}$ of elasper shorter, narrower, not being longer than hindtarsal segment IV, with one long bristle, the second long bristle of $\mathrm{Ct}$. agyrtes being here represented by a small one which is placed near the bottom of the sinus ; $\mathrm{P}^{2}$ quite different from that process of $C t$. agyrtes, half as long again as $\mathrm{P}^{1}$, sublinear, apically slightly dilated, in middle less than half as broad as ventral arm of IX. st. ; the acetabular bristle placed at its posterior margin as thin as, and shorter than, the longest bristle of IX. st. Exopodite F more strongly narrowed apicad than

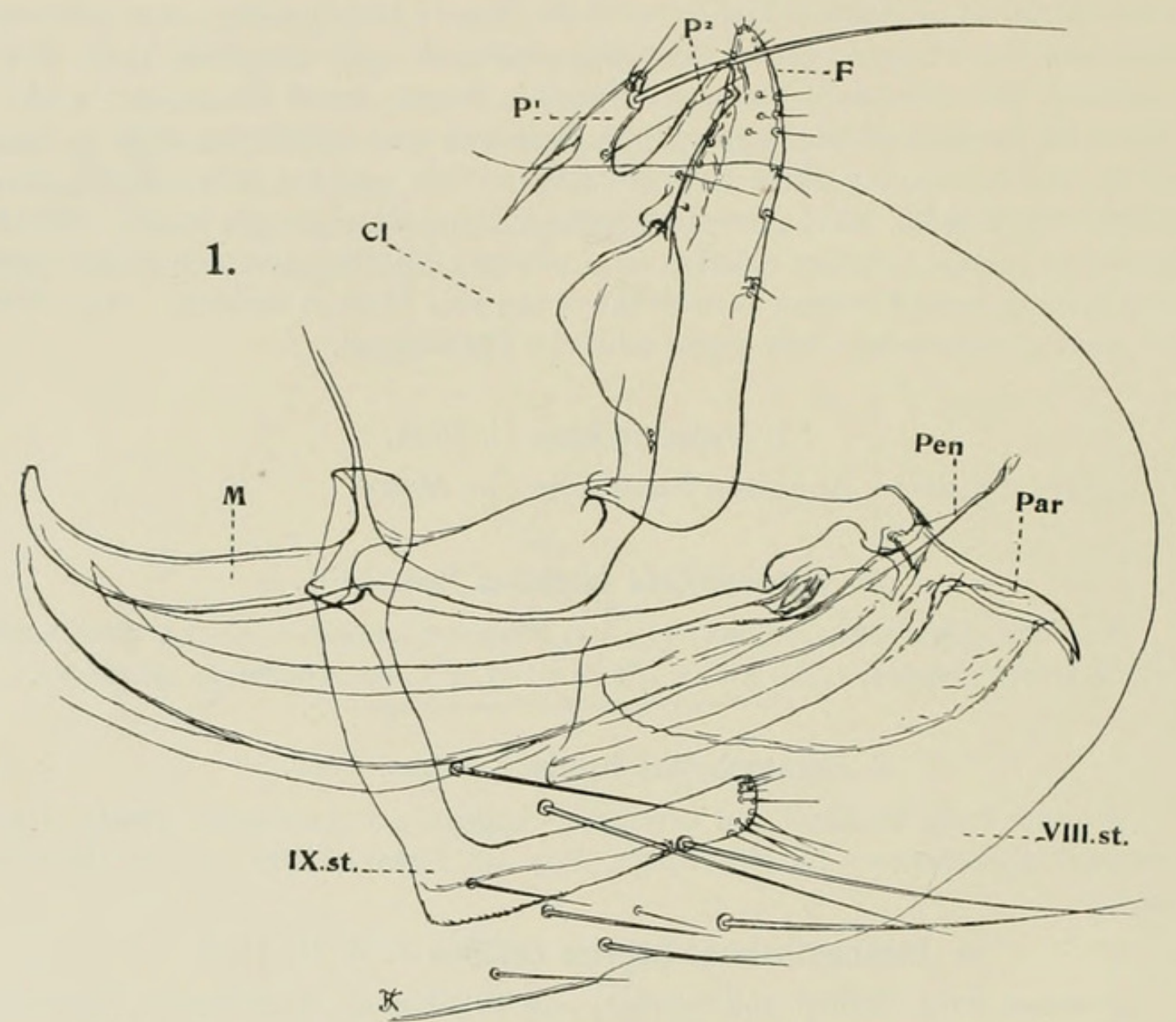

FIG. 1.-Ctenophthalmus arvernus.

in Ct. a. celticus, its apex slightly curved frontad. The two arms of IX. st. broader than in Ct. a. celticus; ventral arm straight, apically obtuse, lower apical angle strongly rounded off, effaced, upper angle less rounded, projecting farther distad, bristles confined to apex. Ventral apical hooks of parameres of penis longer than in $C t$. agyrtes, the apical portion of parameres above duct (Pen) correspondingly shorter ; ventral membrane without the denticulate flap (usually turned up) of $C t$. a. celticus.

․ . On abdominal tergite VII, as a rule, with fewer bristles in front of the posterior row than in $C t$. a. celticus from the same places, the numbers being 8 to 12 (average 10.4 in the specimens examined) in Ct. arvernus, and 12 to 21 in Ct. a. celticus (average 15·3). Narrow subventral apical lobe of VII. st. short, in $C t$. a. celticus long (but individually variable). 
Hab.-Ruffec and places near Ruffec, Charente, August, a series on A podemus sylvaticus, Mus musculus and Evotomys glareolus.—La Bourboule, Puy de Dôme, and places near, 1,200 and 1,700 m., September, a series off the same hosts. Type from Ruffec ô.

6. Rhadinopsylla pentacanthus Roths. 1897.

La Bourboule, Puy de Dôme, 1,200 m., September, 1 †, on Microtus agrestis bailloni.

7. Doratopsylla dasycnemus Roths. 1897.

Poitiers, August, 1 ; , on Crocidura russula.

\section{Palaeopsylla minor Dale 1878.}

Ruffec and places near, Charente, August, a small series, on Talpa europaea.

\section{Leptopsylla segnis Schoenh. 1816.}

Condac near Ruffec, Charente, August, 1 ô, 2 우, on Mus musculus.—La Bourboule, Puy de Dôme, 1,200 m., September, $1 \hat{\jmath}$, on Evotomys spec.

\section{Leptopsylla}

fallax Roths. 1909.

Puy de Dôme district, $1,700 \mathrm{~m}$., September, one pair, on Evotomys glareolus.

\section{Saphiopsylla gen.} nov.

§ิㅇ․ Near Ty-

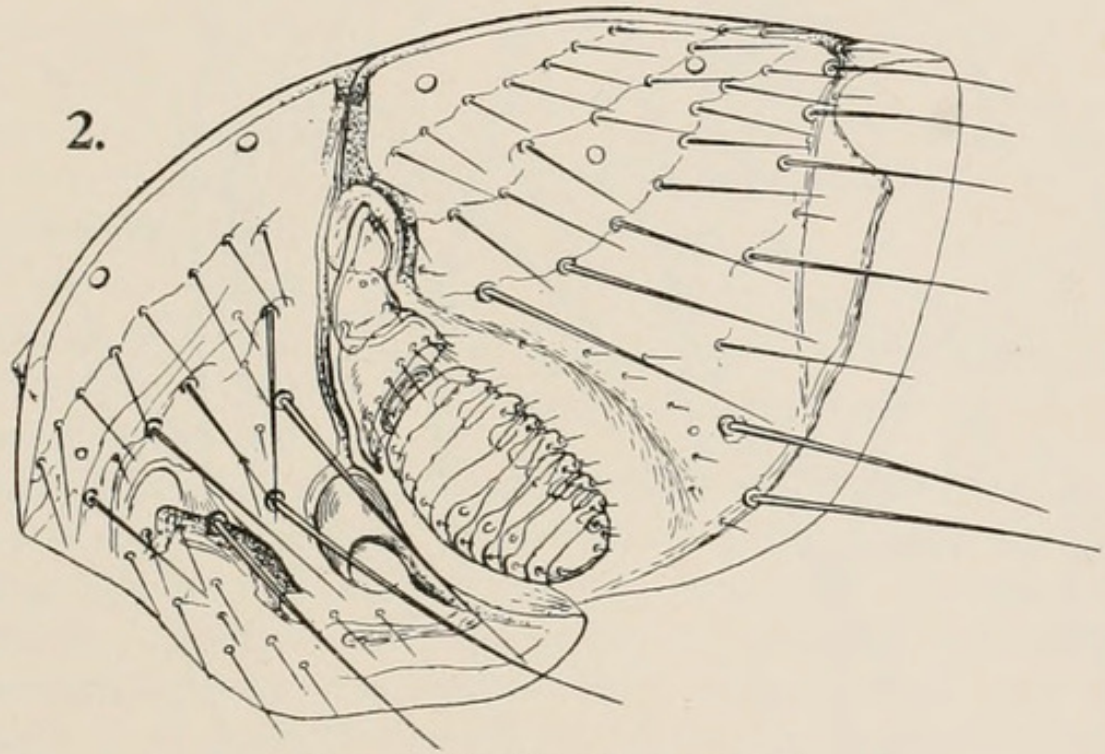
phloceras Wagner

FIG. 2.-Saphiopsylla nupera, 우.

1903, but at once distinguished by the absence of the genal comb (text-fig. 2). Eye smaller than in Typhloceras; maxillary palpus reaching to trochanter, somewhat longer than proboscis; abdominal tergites I to VI with apical spines, these vestigial combs more dorsal than in Typhloceras; stigma-cavity of VIII. t. shorter and apically wider, especially in $q$. Otherwise closely agreeing with Typhloceras, apart from the tail-ends.

Genotype: spec. nov. here described.

11. Saphiopsylla nupera spec. nov. (text-figs. 2, 3, 4).

${ }^{1}+\mathrm{H}_{\text {. }} \mathrm{H}$ e a d . Frontal tubercle prominent. Three rows of bristles on frons, four on occiput; several small additional bristles obliquely below eye behind the long ones; three long bristles in front of eye, the uppermost close to antennal groove and more forward than the other two; no such long bristle near oral margin. 
Th o r a x.-Pronotum with two rows of bristles and a comb of 21 or 22 spines. Mesonotum with three rows and numerous additional small bristles in front of the rows. Mesopleura in 8 with 16 or 17 bristles, in $q$ with 21 . Metanotum with three rows and in $q$ with some additional bristles. Metepimerum in $\delta$ with 10 or 11 , in $q$ with 16 .

A b d o m e n.-Apical spines on tergites (the two sides together) in of on I 7 , II 10 or 15 , III 10 , IV 7 or 10 , V 6 , VI 3 ; in ㅇ on I 8 , II 11 , III 10 , IV 10 , V 6, VI 2. In of tergites I and II with three rows of bristles, on the other tergites two, with very few additional dorsal bristles, which are more numerous in $q$; numbers of bristles, on the two sides together : in of on III 24 or 26,15 or 16 ,

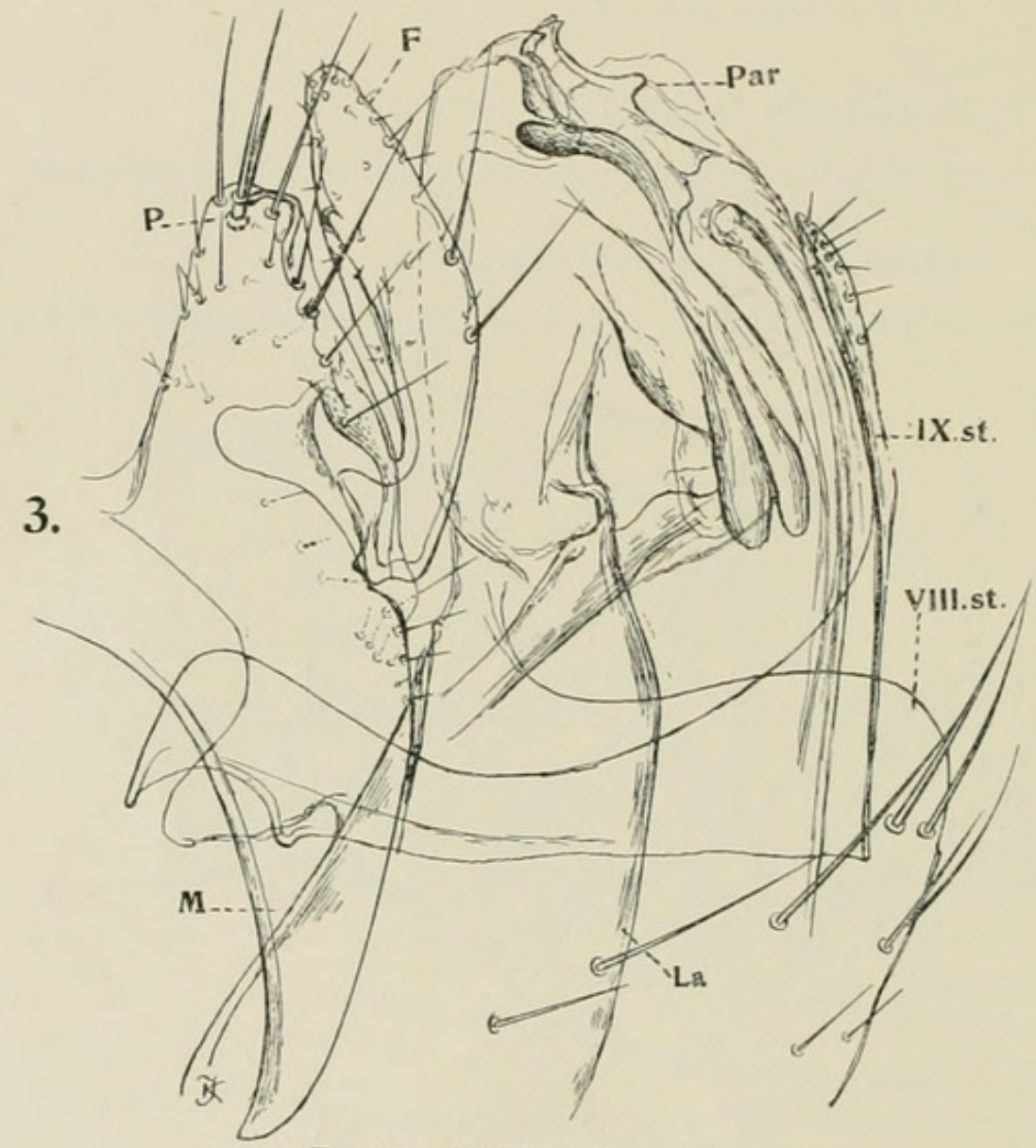

FIG. 3.-Saphiopsylla nupera.

IV 20 or 22,15 , VI 14 or 17,13 , VII 12 or 15,11 , in 9 on III 38,15 , IV 29, 13, VI $17,11, \mathrm{VII}, 128$. One long bristle of the tergites lower than stigma. Bristles on sternites: in $\hat{\sigma}$ on III 8 or 9 , IV 8 or 10 , V 9 or 10 , VI 10, VII 10 or 11 ; in $q$ on III 19, IV 21, V 21, VI 23, VII 39.

Legs.-Inner surface of hindeoxa with small hairs to or a little above middle. Hindfemur with a row of $4(\hat{\jmath})$ or $5(+)$ bristles in posterior half. On hindtibia two rows of lateral bristles, together 20 to 26 , there being a space between these rows and the subventral bristles. Proportional lengths of tarsal segments: midtarsus in ôे $26,19,12,9,17$ and $28,20,12,8,18$, in 우

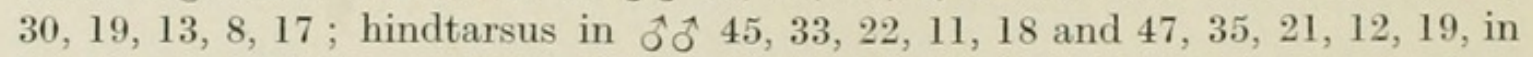
ㅇ $53,36,20,12,19$.

Modified Seg ments.—ô: On VIII. st. (the two sides together) with 19 bristles, two of the long ones on each side being subapical ; apical margin strongly rounded ventrally. Clasper almost gradually narrowed to form the manubrium (M) ; distance from base of exopodite $\mathrm{F}$ to tip of manubrium about one-fifth longer than F. Process $\mathrm{P}$ of clasper conical, truncate, basally $2 \frac{1}{2}$ times as broad as apically, along anterior margin one-sixth longer than it is broad at base; on outer surface of $\mathrm{P}$ three long apical bristles, several small lateral ones and a posterior marginal row of 4 or 5 , of which the second or third is long, the bristles variable in length; on innerside a short and very stout subapical bristle. Exopodite $\mathrm{F}$ four times as long as broad, widest in middle, narrowing 
to base and to apex, posterior margin more strongly rounded than anterior, apex rounded, in apical fourth around apex a number of minute marginal bristles, at posterior margin a long slender bristle above middle and another below middle. Anterior vertical margin of IX. st. at a right angle with ventral margin ; posterior margin of dilated apex of vertical arm rounded, this arm gradually widening on posterior side, the posterior margin being nearly evenly incurved from near apex to bottom ; ventral arm of IX. st. very narrow, slightly lanceolate distally, with about 7 short and very thin bristles on outer surface from threefourths to apex. Internal lamina of penis (La) very broad, its proximal end broadly rounded. $-q$ : Apical margin of VII. st. deeply incised, the sinus about three times as deep as broad in middle, its greatest width being equal to the length of midtarsal segment IV; lower lobe rounded, subtruncate, upper lobe with the dorsal margin oblique and rounded, ventral margin nearly straight, the apical angle formed small, but rounded off, not pointed (text-fig. 4). VIII. t. with 17 or 18 bristles on the outer side of the widened ventral area (each side) and 9 on inside, the apical margin of this portion of the segment rounded; above stigma about six short bristles on each side. Pygidium very feebly convex. Stylet cylindrical, a little over twice as long

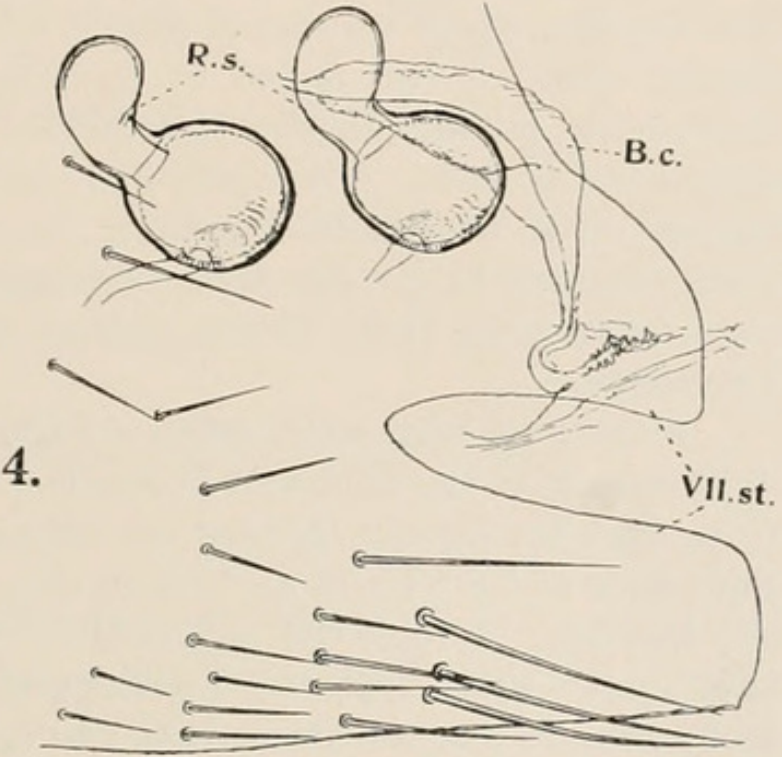

FIG. 4.-Saphiopsylla nupera. as broad. Anal sternite unlike that of Typhloceras without small lateral bristles ; on ventral surface proximally of middle a bunch of about 12 bristles (on the two sides together), a solitary long median one and near apex on each side two long bristles. Bursa copulatrix (B.c.) long and broad, gradually narrowing towards both ends, about three times as long as broad, convex dorsally (i.e. on posterior side), possibly divided longitudinally, its width equalling that of the sinus of VII. st. Two spermathecae (R.s.) which are alike; body globular, tail as long as body, a little over half its width, strongly rounded apically, without appendix.

Length : ô 2.4 to $2.6 \mathrm{~mm}$. ; $2.9 \mathrm{~mm}$. ; hindfemur : ô 0.45 to $0.48 \mathrm{~mm}$. ; 우 $0.55 \mathrm{~mm}$.

Hab. La Bourboule, Puy de Dôme, 1,200 m., September, 2 ô $\hat{o}, 1$ ㅇ, one specimen each on Evotomys spec., Evotomys glareolus and Microtus agrestis bailloni.

\section{Hystrichopsylla talpae Curtis 1826 .}

Puy de Dôme district, 1,700 m., September, $2 \hat{o} \hat{o}$, on Sorex araneus.

In one specimen the fourth abdominal comb is represented by 2 spines on one side and by 3 on the other ; in the second specimen the numbers are 0 on one side and 2 on the other. 


\section{$2 \mathrm{BHL}$ Biodiversity Heritage Library}

1931. "Siphonaptera collected by Mr. F. J. Cox in France." Novitates zoologicae: a journal of zoology in connection with the Tring Museum 36, 225-229. https://doi.org/10.5962/bhl.part.10113.

View This Item Online: https://www.biodiversitylibrary.org/item/23084

DOI: https://doi.org/10.5962/bhl.part.10113

Permalink: https://www.biodiversitylibrary.org/partpdf/10113

\section{Holding Institution}

Natural History Museum Library, London

\section{Sponsored by}

Natural History Museum Library, London

\section{Copyright \& Reuse}

Copyright Status: In copyright. Digitized with the permission of the rights holder.

Rights Holder: The Trustees of the Natural History Museum, London

License: http://creativecommons.org/licenses/by-nc-sa/4.0/

Rights: http://biodiversitylibrary.org/permissions

This document was created from content at the Biodiversity Heritage Library, the world's largest open access digital library for biodiversity literature and archives. Visit BHL at https://www.biodiversitylibrary.org. 